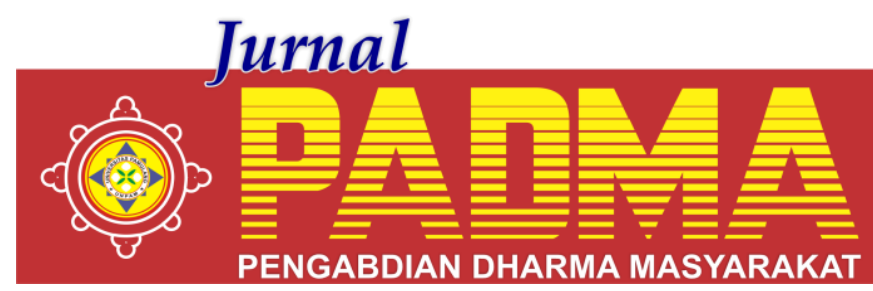

VOLUME 1, NOMOR 2, APRIL 2021

\title{
PELATIHAN PERSONAL FINANCIAL HEALTH CHECK-UP PADA KEUANGAN KELUARGA KETIKA PANDEMI COVID-19
}

\author{
${ }^{1 *}$ Kharisya Ayu Effendi, ${ }^{2}$ Denny Saputera, ${ }^{3}$ Sakina Ichsani \\ Universitas Widyatama Bandung, Jawa Barat, Indonesia \\ *kharisya.ayu@widyatama.ac.id
}

\begin{abstract}
Abstrak
Pandemi Covid-19 telah mempengaruhi tatanan hidup dan kebiasaan masyarakat di dunia pada umumnya dan di Indonesia pada khususnya. Kesehariannya masyarakat yang telah terbiasa untuk berinteraksi secara langsung, karena adanya Covid-19 maka masyarakat harus mulai terbiasa dengan pola hidup sehat yaitu dengan penerapan social distancing. Keuangan keluarga mengalami dampak yang buruk akibat pandemi Covid-19. Implementasi pelaksanaannya dengan memberikan pembelajaran melalui daring dengan menggunakan aplikasi google meet dan dilanjutkan dengan melalui forum diskusi tanya jawab dengan mitra yang tergabung dalam KADIN Jawa Barat. Di masa pandemi Covid-19, keluarga harus mampu mengimplementasikan financial health chek up didalam keuangan rumah tangganya. Karena menurunnya keuangan keluarga berdampak pada menurunnya konsumsi belanja rumah tangga dapat berakibat pada menurunnya pertumbuhan perekonomian suatu negara. Strategi yang dapat digunakan oleh keluarga dalam menempuh kondisi masa pandemi Covid-19 ini adalah dengan mencatat dan merinci dari setiap pengeluaran dan pemasukan, membuat budget untuk setiap pengeluaran dan menghindari pengeluaran yang tidak perlu.
\end{abstract}

Kata Kunci :Personal Financial Health Check-Up, Keuangan Keluarga, Pandemi Covid-19

Abstract

The Covid-19 pandemic has affected the way of life and habits of people in the world in general and in Indonesia in particular. On a daily basis, people who are accustomed to interacting directly, because of Covid19, people must start to get used to a healthy lifestyle, namely the application of social distancing. Family finances were badly affected by the Covid-19 pandemic. The implementation of the implementation is by providing online learning using the google meet application and continued by going through a question and answer discussion forum with partners who are members of the West Java KADIN. During the Covid-19 pandemic, families must be able to implement financial health check-ups in their household finances. Because the decline in family finances has an impact on decreasing consumption of household spending, it can result in a decline in the economic growth of a country. The strategy that can be used by families in dealing with the conditions of the Covid-19 pandemic is to record and detail each expenditure and income, create a budget for each expense and avoid unnecessary expenses.

Keywords: : Personal Financial Health Check-Up, Family Finances, Covid-19 Pandemic

\section{PENDAHULUAN}

Pandemi Covid-19 di Indonesia merupakan bagian dari pandemi penyakit Corona virus 2019 (Covid-19) yang saat ini sedang berlangsung di seluruh dunia. Penyakit ini disebabkan oleh Coronavirus yang merupakan penyakit yang bercirikan seperti sindrom pernapasan akut berat 2 (SARS-CoV-2). Awal mula kasus positif Covid-19 di Indonesia terdeteksi pada awal Maret 2020 ketika dua orang terkonfirmasi tertular melalui seorang warga negara Jepang. Pada tanggal 9 April 2020, pandemi sindrom pernapasan akut ini diketahui sudah menyebar ke 34 provinsi di Indonesia. Provinsi dengan tingkat paparan tertinggi adalah DKI Jakarta, Jawa Timur dan Jawa Barat yang diketahui sebagai daerah dengan paparan tertinggi di Indonesia. Satu tahun setelah dikonfirmasikannya penyebaran virus ini yaitu hingga tanggal 26 Februari 2021, pemerintah Indonesia telah melaporkan 1,31 juta kasus positif Covid-19. Hal ini membuat Indonesia menjadi negara dengan peringkat pertama terbanyak pasien terpapar positif virus Covid-19 se-Asia 
Tenggara. Sedangkan angka kematian akibat virus Corona ini, Indonesia menduduki peringkat ketiga tertinggi di Asia dengan dilaporkan sebanyak lebih dari 35 ribu jiwa meninggal.

Pandemi Covid-19 telah

mempengaruhi tatanan hidup dan kebiasaan masyarakat di dunia pada umumnya dan di Indonesia pada khususnya. Kesehariannya masyarakat yang telah terbiasa untuk berinteraksi secara langsung, karena adanya Covid-19 maka masyarakat harus mulai terbiasa dengan pola hidup sehat yaitu dengan penerapan social distancing. Adanya Covid-19 juga telah mempengaruhi kegiatan perekonomian. Perkiraan kinerja perekonomian Indonesia sampai awal tahun 2021 diperkirakan hanya akan tumbuh sebesar 4,8\%. Pertumbuhan ini lebih rendah dibandingkan capaian pertumbuhan tahun 2019 sebesar 5,02\%. Penurunan pertumbuhan ini disebabkan oleh pandemik Covid-19 yang mengakibatkan menurunannya pertumbuhan perekonomian di seluruh dunia dan terjadinya penurunan daya beli masyarakat.

Sebagai akibat dari adanya pandemic Covid-19 dan diberlakukannya social distancing berupa PSBB (Pembatasan Sosial Berskala Besar) maka perekonomian pun secara umum mulai melemah. Namun kegiatan perekonomian di Indonesia diharapkan dapat bisa kembali pulih mulai bulan Juni 2021 seiring dengan telah diterapkan vaksin Covid-19.

\section{METODE}

Metode pelaksanaan adalah dengan memberikan pengajaran lewat daring yaitu menggunakan aplikasi googlemeet dan kemudian dilanjutkan dengan melakukan forum diskusi tanya jawab mengenai permasalahan yang dihadapi ketika terjadi pandemi Covid-19 dan upaya yang akan dilakukan ketika memasuki tahap new normal. Forum diskusi tanya jawab ini diharapkan menjadi sarana penghubung antara tutor dari Fakultas Ekonomi dan Bisnis Universitas Widyatama dan mitra KADIN Jawa Barat.

Tahap pertama pelaksanaan kegiatan adalah dengan melakukan peninjauan lapangan dan berkoordinasi dengan para mitra. Dalam hal ini dosen pengabdi berkoordinasi dengan para pengambil kebijakan di KADIN Jawa Barat untuk memetakan masalah (poin) yang dihadapi oleh para mitra secara umum.

Tahap kedua pelaksanaan pengabdian kepada masyarakat ini adalah dengan pengajuan proposal pengabdian kepada masyarakat untuk mendapatkan izin secara tertulis dari pihak universitas dan mendapatkan izin tertulis dari pihak mitra yakni diwakili oleh KADIN Jawa Barat.

Tahap ketiga yaitu setelah melakukan peninjauan lapangan dan mengajukan proposal, maka dilakukan social mapping untuk setiap peserta dengan memberikan kuesioner yang bersifat tertutup. Social mapping ini bertujuan agar para tutor mendapatkan gambaran mengenai permasalahan yang dihadapi oleh setiap mitra secara spesifik, terperinci dan juga agar para mitra mendapatkan bayangan mengenai materi yang akan didapatkan.

Pada tahap selanjutnya, para tutor berdiskusi mengenai materi yang akan diberikan. Para tutor juga berdiskusi dan bertukar pikiran mengenai masalah yang banyak dihadapi oleh mitra. Kemudian para tutor mempersiapkan solusi terbaik dari permasalahan yang dihadapi oleh para mitra.

Pada tahap kelima ini kegiatan pengabdian kepada masyarakat dilakukan dengan mempertemukan para tutor dan mitra menggunakan forum googlemeet sesuai dengan waktu yang disepakati bersama.

Tahap terakhir adalah melakukan evaluasi dan monitoring. Cara melakukan evaluasi dan monitoring yaitu dengan cara memberikan kuesioner akhir mengenai kegiatan pengabdian kepada masyarakat menggunakan forum googlemeet dan membuka forum diskusi setelah acara selesai.

Kegiatan ini yang dimulai dari peninjauan lapangan hingga evaluasi dan monitoring menghabiskan waktu selama 5 bulan, yaitu dari bulan November 2020 hingga bulan Maret 2021.

\section{HASIL DAN PEMBAHASAN}

Financial Health Chek Up merupakan langkah awal untuk keluarga mengetahui apakah kondisi keuangan dalam rumah tangganya sehat atau tidak. Dalam 
penerapannya Financial Health Check Up dapat dilakukan dengan melihat aspek penting yang berhubungan dengan sistem keuangan, yaitu seperti Total Aset yang dimiliki, Total Hutang atau Kewajiban, Total Pendapatan dan Pengeluaran dan Total Tabungan yang dimiliki. Selain bisa mengetahui kondisi sistem keuangan, keuntungan melakukan Financial Health Check Up adalah sebagai berikut :

1. Dapat Menjaga Kondisi Kesehatan Keuangan

Software akuntansi yang banyak beredar tidak dapat mendeteksi sepenuhnya kondisi kesehatan keuangan karena software tersebut tidak dapat menjangkau sisi sumber daya manusia yang mengelola atau yang menjadi objek penilaian. Financial check-up berguna untuk mengetahui dan memperkecil masalah keuangan karena masalahmasalah mikro dalam keuangan.

2. Penggunaan Uang dapat Menjadi Lebih Bijak

Financial Check-Up dapat menyebabkan penggunaan dana menjadi lebih hati-hati dan bijaksana. Hal ini dikarenakan penggunaan uang yang tidak jelas atau kurang memberikan pengaruh positif dapat diminimalisir. Penggunaan dana untuk kebutuhan pribadi juga dapat diminimalkan dengan adanya financial check-up.

3. Dapat mengetahui arus dana keuangan

Financial Check-Up dapat digunakan untuk mengetahui keperluan dan kebutuhan apa saja dalam kehidupan sehari-hari. Dengan mengetahui hal tersebut, maka arus dana akan lebih terarah karena sudah dibantu oleh financial check-up.

4. Merencanakan Kegiatan yang Akan Datang

Ketika keuangan sudah lebih terarah dan terencana, maka harapanharapan serta visi misi keuangan di masa yang akan datang dapat lebih terarah.

5. Dapat Mengetahui dengan Pasti Hutang

Kondisi keuangan yang baik tidak hanya memiliki jumlah tabungan yang cutup, namun juga memiliki hutang yang sedikit atau lebih baik lagi tidak memiliki hutang. Terkadang yang terjadi adalah jumlah tabungan yang cukup, namun diiringi dengan jumlah hutang atau cicilan yang besar. Dengan adanya financial check-up maka kondisi ini dapat dihindari.

6. Kondisi Keuangan Ideal untuk Jangka Panjang dan Menengah

Financial Check-Up membantu perusahaan atau keluarga dalam merencanakan keuangan tidak hanya untuk jangka pendek namun juga untuk jangka menengah dan panjang. Financial Check-Up membantu keluarga untuk memastikan rencana-rencana jangka panjang dan menengah dapat dicapai tepat pada waktunya.

7. Dapat memulai investasi

Apabila memiliki dana lebih dan tidak lagi memiliki hutang, maka dapat direncanakan untuk memulai investasi atau membuka bisnis.

Tujuan dari melakukan pengecekan kesehatan keuangan adalah untuk dapat mengetahui kesehatan keuangan dan dapat mengelola keuangan lebih baik. Maka dari itu, melakukan hal ini tidak terbatas pada sebuah usaha atau berpenghasilan besar saja, namun seorang individu atau keluarga dan berpenghasilan cukup pun harus melakukan pengecekan kesehatan keuangan ini atau financial health check up.

Dalam memeriksa kondisi keuangan finansial dapat dilakukan saat ini, karena dalam membuat memeriksa kondisi finansial dan melaksanakan aktifitas keuangan sesuai perencanaan merupakan suatu hal yang penting untuk dilakukan.

Selanjutnya keluarga tinggal melakukan strategi finansial berikut supaya bisa meraih kondisi keuangan yang lebih baik. Berikut ini adalah hal-hal yang dapat diketahui dengan memeriksa kondisi finansial yaitu dengan cara membukukan seluruh pemasukan serta pemasukan, membuat rencana pengeluaran dan menghindari pengeluaran yang tidak diperlukan.

Setiap pemasukan dan pengeluaran harus dicatat, baik menggunakan pencatatan manual buku, dengan bantuan Microsoft excel ataupun menggunakan software keuangan. Tujuannya adalah untuk mengetahui setiap pengeluaran dan pemasukan. Setelah mengetahui pengeluaran 
dan pemasukan, kemudian dapat dilakukan evaluasi untuk perbaikan kedepannya.

Sebelum melakukan pengeluaran dana, maka sebaiknya dibuat sebuah perencanaan. Perencanaan tersebut dikategorikan berdasarkan kebutuhan dan gaya hidup masing-masing rumah tangga. Dengan adanya perencanaan, maka pengeluaran untuk kebutuhan yang tidak penting dapat dihindari.

Dengan adanya perencanaan keuangan, maka dapat diukur jumlah pengeluaran yang akan terjadi. Namun selalu dipastikan untuk menghindari setiap pengeluaran-pengeluaran yang tidak perlu dilakukan atau dapat ditunda. Dengan menghindari hal-hal tersebut, maka pengeluaran dapat ditekan.

\section{PENUTUP}

Pada saat pandemi Covid-19 ini, sudah saatnya keluarga memperhatikan kesehatan keuangan rumah tangganya agar tetap dapat hidup dengan nyaman. Dikarenakan guncangan pada keuangan keluarga dapat berdampak pada pertumbuhan perekonomian dalam suatu negara. Apabila konsumsi menurun, segala bentuk usaha jual beli menjadi lemah atau menurun. Apabila keuangan keluarga kurang baik, tabungan tentunya banyak terkuras, saham dan obligasi juga banyak dijual. Hal ini dapat berdampak besar bagi pertumbuhan perekonomian dalam suatu negara. Oleh sebab itu, sebaiknya keluarga mulai menerapkan financial healt chek up dan menerapkan langkah-langkah finansial yang baik agar dapat meraih kondisi keuangan yang lebih baik.

\section{DAFTAR PUSTAKA}

Agus, Sartono, Manajemen Keuangan: Teori dan Aplikasi. Edisi Keempat. Yogyakarta: BPFE. 2010.

Darminto, Dwi Prastowo. Analisis Laporan Keuangan. UPP STIM, YKPN, Yogyakarta, 2011.

Darsono. Pedoman Praktis Memahami Laporan Keuangan. Andi, Yogyakarta. 2008.

Fahmi, Irham. Analisis Kinerja Keuangan. Alfabeta, Bandung. 2009.

Halim, Abdul. Auditing. UPP STIM YKPN, Yogyakarta. Harmono. 2009.
Manajemen Keuangan. PT. Bumi Aksara, Jakarta, 2008.

Harahap, Sofyan Syafri, Analisis Kritis atas Laporan Keuangan, Rajawali Press, Jakarta, 2015

Hery. Analisis Laporan Keuangan. Bumi Aksara, Jakarta.2015.

I Made Sudana, Manajemen Keuangan Teori dan Praktik, Airlangga University Press, Jakarta, 2011.

John Fred Weston, Eugene F. Brigham, Managerial Finance, Business and

Economics: Finance Holt, Saunders International Dryden Press,University of California, 2008.

Jumingan, Drs., Analisis Laporan Keuangna, Bumi Aksara, Jakarta, 2008.

Kasmir. Analisis Laporan Keuangan. Edisi 7. Raja Grafindo Persada, Jakarta, 2016.

Lawrence Revsine and Daniel Collins and Bruce Johnson and Fred Mittelstaedt and Leonard Soffer, Financial Reporting \& Analysis, 7th edition, Mc. Graw Hill, 2017.

Mahmoedin.AS, Melacak Kredit Bermasalah, Pustaka Sinar Harapan. Jakarta. 2004.

Mamduh M. Hanafi dan Abdul Halim, Analisa Laporan Keuangan, edisi 9, UPP STIM YKPN, Yogyakarta, 2009.

Muhardi, Analisa Laporan Keuangan, 2013.

Munawir, Drs. S. Akuntan, Analisa laporan keuangan. Liberty, Yogyakarta, 2010.

Nufus, K., Supratikta, H., Muchtar, A., Sunarsi, D. (2020). Analysis of Financial Performance: Case Study of PT. X Employee Cooperative. Utopía Y Praxis Latinoamericana. Año: 25, $\mathrm{N}^{\circ}$ Extra 10, 2020, pp. 429-444.

Rudiantoro, Rizki. Sylvia Veronica Siregar. 2012. Kualitas Laporan Keuangan UMKM Serta Prospek Implementasi SAK ETAP. Jurnal Akuntansi dan Keuangan Indonesia Vol 9 No 1 Juni 2012.

Sugiono Arief, Untung, Edi, Panduan Praktis Dasar Analisa Laporan Keuangan, Pengetahuan Dasar bagi Mahasiswa dan Praktisi Perbankan, Grasindo, Jakarta, 2016.

Supramono Gatot, Perbankan dan masalah kredit, Rineka Cipta, Jakarta, 2009. 